УДК 342.9

DOI https://doi.org/10.32837/pyuv.v2i4(29).445

\author{
К.В. Кравченко \\ orcid.org/0000-0001-9132-4550 \\ аспірант кафедри адліністративного та господарського права \\ Одеського національного університету імені I. I. Мечникова
}

\title{
ДО ПИТАННЯ ДІДЖИТАЛІЗАЦІЇ ІНСТИТУТУ АПЕЛЯЦІЙНОГО ПРОВАДЖЕННЯ
}

Розвиток сучасних інформаційно-комунікаційних технологій впливає сьогодні майже на всі сфери життя. Цифрова трансформація, або діджиталізація - це реальність нашого життя, бо повсякденне життя вже неможливо уявити без електронної комерції, мобільного або SMS-банкінгу й інших різноманітних сервісів. Тобто діджиталізацію варто розглядати як процес змін у всіх сферах суспільної діяльності під впливом інтеграції цифрових технологій, діджиталізованих даних і мережі Інтернет.

Україна теж не стоїть осторонь. Наприклад, в Україні працбє Єдиний вебпортал державних послуг «Дія», який надасть можливість отримувати публічні послуги, подавати звернення, скарги, петиції, здійснювати електронне листування 3 органами влади, проводити опитування. Авторизація на порталі (за допомогою електронного підпису, BankID або MobileID) дозволить кожному українцю знайти всі дані про себе, персональні документи на власне майно, отримати потрібну послугу, а в майбутньому і проголосувати [1].

Метою статті є визначення впливу діджиталізації на інститут апеляційного провадження, дослідження міжнародного досвіду у площині застосування новітніх технологій у судовому процесі.

Згідно з дослідженням Глобального інституту McKinsey за 2018 р., «діджиталізація може стати наступним драйвером зростання Центральної та Східної Європи» [2]. Цей висновок безпосередньо стосується й України. Драйвери економічного зростання - сукупність механізмів, які вловлюють попит, каталізують імпульси, що йдуть від економіки, включають на відповідному етапі різні активи (матеріальні, фінансові, інформаційні, трудові) у русло руху, змінюють економічну ситуацію у країні [3]. Хоча навколо відбуваються надзвичайно динамічні технологічні зміни, які мають реальний вплив на всі сфери суспільства, але ці сфери перебувають у недостатньо врегульованому правовому просторі. Тому, безперечно, викликами сьогодення є застосування новітніх технологій і в діяльності публічних органів влади, належне їх правове застосування.

Під час здійснення судової реформи Україна використовує позитивний досвід різних країн світу, який уже напрацьований і перевірений часом. Так, наприклад, основні вектори цифрової трансформації охарактеризовано в дослідженнях Організації економічного співробітництва та розвитку [4].
Використовуючи все найефективніше, Україна може заощадити кошти, ухвалювати перевірені часом позитивні рішення. Наприклад, досвід Азії дозволив країнам Латинської Америки і Свропи зробити процес діджиталізації більш адекватним. Якщо азійські суди діджиталізувались десь за 10 років, європейські країни, розпочавши процес приблизно у 2007-2009 рр., уже зараз мають успішно працюючу систему [5]. У більшості африканських країн, навіть у Папуа-Новій Гвінеї є система електронного суду, яка працює чотирма мовами [5]. Тому діджиталізація національних судів - це гострий виклик сьогодення і незворотний процес в умовах технологічної революції, інформатизації суспільства.

О. Кобенко, зазначає, що діджиталізація - це формат відносин end-to-end direct online procedure, який передбачає наявність трьох складників, як-от: а) безперервна процедура он-лайн а (англ. end-toend) - процедура, жодний елемент якої не передбачає необхідності використання паперового носія чи фізичної присутності; б) пряма процедура он-лайн (англ. direct) - процедура, яка може бути проведена напряму самостійно кінцевим споживачем, тобто без втручання посередника чи компетентного органу; в) процедура он-лайн (англ. on-line) - процедура, яка може здійснюватись через вебмережу і доступна для кінцевих споживачів послуг [6].

Діджиталізація суттєво впливає на трансформацію інституту апеляційного провадження. Використання формату end-to-end direct online procedure під час організації та проведення апеляційного провадження істотно змінюе як систему апеляційних адміністративних судів, так і порядок апеляційного провадження. Цікавий щодо цього досвід Великобританії, де створюється єдина система онлайн-судів (Online dispute resolution system), призначена для розгляду найбільш поширених цивільних позовів до 25 тис. фунтів. Система дозволить громадянам економити кошти та врегульовувати свої спірні питання навіть без втручання юриста. Також Великобританія має плани щодо створення «мобільних судів», з онлайн-доступом до них у громадських місцях [7].

Завдяки «осучасненню» інституту апеляційного провадження використанням новітніх технологій цей інстанційний рівень розгляду адміністративних справ переходить на новий етап розвитку та створюються додаткові можливості для учасників судового 
процесу захищати й обстоювати свої права, інтереси в адміністративному судовому процесі.

На рівні інституту апеляційного провадження впроваджуються сучасні інформаційно-телекомунікаційні технології, зокрема: а) системи електронного документообігу (правовим підгрунтям діяльності якої є Положення про автоматизовану систему документообігу суду (далі - АСДС), затверджене рішенням Ради суддів України (далі- РСУ) від 26 листопада 2010 p. № 30 (у редакції рішення РСУ від 12 квітня 2018 р. № 16) [8]; б) системи дистанційного розгляду справ; в) електронні підписи й інші прояви. Безумовно, діджиталізація впливає на строки розгляду справ, оскільки документообіг здійснюватиметься набагато швидше. Крім того, сторони мають можливість набагато швидше ознайомлюватися з матеріалами справи. Це все в сукупності сприятиме більш динамічному розгляду справ [9].

В Україні ведеться робота із запровадження Єдиної судової інформаційно-телекомунікаційної системи (далі - ЄСITC), коли вона запрацює на повну, то учасникам судового процесу суд буде вручати документи у справах виключно в електронній формі, шляхом їх надсилання на офіційну електронну адресу особи. Суд буде проводити розгляд справи за матеріалами судової справи в електронній формі. Безперечно, усі зазначені вище новели є позитивними, адже переведення більшої частини адміністративного судочинства у площину віртуального простору, обмеженого ЄCITC, дозволить більш ефективно виконувати завдання адміністративного судочинства, передбачені в ч. 1 ст. 2 Кодексу адміністративного судочинства України (далі - КАСУ) [10].

Важливою складовою частиною ЄСITC, однією із восьми, є підсистема (модуль) Електронного суду. P. XI рішення Ради суддів України від 26 листопада 2010 р. № 30 [11] закріплює праве підгрунтя роботи Електронного суду (e-court ) в Україні. Перші кроки з упровадження e-court були зроблені в середині 2018 р., коли Державна судова адміністрація України (далі - ДСА України) встановила пілотні суди, які мали розпочати роботу з Електронним судом. Так, 1 грудня 2018 р. в газеті «Голос України» було опубліковане оголошення про створення та забезпечення функціонування ЄCITC із 1 березня 2019 р. у складі 8 підсистем (модулів), зокрема електронного суду. Але вже 1 березня 2019 р. на підставі рішення Вищої ради правосуддя від 28 лютого 2019 р. № 624/0/15-19 «Про повернення на доопрацювання проєкту Положення про Єдину судову інформаційно-телекомунікаційну систему» [8] ДСА України опублікувала повідомлення про відкликання оголошення про створення та забезпечення функціонування ЄCITC. Але використання ЄCITC в Україні - це лише справа часу. Система електронного судочинства впроваджується в Україні за підтримки Європейського Союзу (далі - ЄС), зокрема проєкту ЄС «Право-Justice” [12], це дозволяє Україні отримува- ти кошти, які прискорюють процес упровадження е-судочинства; створювати систему з урахуванням європейських стандартів тощо. Також ЄСITC об'єднає всіх причетних до правосуддя. Така діджиталізація судових процедур цілковито узгоджується з реалізацією стратегії «Держава у смартфоні».

Використання e-court в апеляційному провадженні в адміністративних судах $є$ кроком уперед та сприяе наближенню національного адміністративного судочинства до передових міжнародних стандартів.

Проте сьогодні Електронний суд (е-суд), як і нормативне регулювання діяльності та взаємодії з ним, залишається недоопрацьованим та потребує значного вдосконалення [13]. Поки система не запрацювала на повну, застосування $e$-court створює деякі проблеми для учасників судового процесу. Наприклад, згідно з даними Ради суддів України, на липень 2019 р. в підсистемі «Електронний суд» було зареєстровано 22,6 тис. користувачів. «До судів засобами «Електронного суду» надіслано 19,9 тис. заяв, 3 яких 17,5 тис. було зареєстровано судами, в тому числі 9,8 тис. - авторозподілені. Більшість судових справ розглянута або їх розгляд триває в судах. Водночас за частиною отриманих через «Електронний суд» документів суди ухвалили 3,5 тис. рішень про залишення заяв без руху у зв'язку з необхідністю їх подання в паперовому вигляді. Це становить $36 \%$ від загальної кількості заяв, поданих через «Електронний суд». Така динаміка відмов у розгляді документів щодня зростає» [14].

Якщо враховувати міжнародний досвід, то можна зазначити, що використання e-court у повному обсязі в Україні - це лише справа часу. Так, процес упровадження електронного суду як цифровізації документів і переходу судової системи від паперових до електронних носіїв датується початком $2000-\mathrm{x}$ рр. Лідерами цього процесу були країни Азії: Корея, Гонконг, Сінгапур та ін. Зараз, наприклад, у судовій системі Гонконгу не лишилось жодного папірця. Навіть наказ про примусове виконання, стягнення тощо в електронному вигляді надсилається судом одразу до виконавчої служби, а копії - боржнику і стягувачу [5].

Однією з перших країн, яка перевела судовий процес на рівень діджиталітації, стала Бразілія. Головна детермінанта впровадження e-court та застосування системи штучного інтелекту (далі - СШI) у зазначеній країні - дуже велика кількість спорів. Наприклад, якщо в Україні на рік розглядається приблизно 4 мільйони спорів, то у Бразилії - приблизно 20 мільйонів [5], тому вони були просто вимушені модернізувати систему шляхом запровадження е-суду та СШ. Цікавим є факт, що системи штучного інтелекту в кожному суді у Бразилії мають власне ім'я, наприклад, у Верховному Суді Бразилії-Сократ [5].

В Україні вже створене правове підгрунтя для діджиталізації судової системи взагалі й інституту 
апеляційного провадження зокрема. До основних нормативно-правових актів, які створюють умови для діджиталізації судів, можна віднести такі закони України: «Про доступ до судових рішень» від 22 грудня 2005 р.; «Про захист інформації в інформаційно-телекомунікаційних системах" від 19 квітня 2014 р.; «Про електронні документи та електронний документообіг» від 30 вересня 2015 р.; «Про доступ до публічної інформації» від 1 травня 2015 р.; «Про електронний цифровий підпис» від 2 листопада 2016 р.; «Про електронні довірчі послуги» від 5 жовтня 2017 р.; «Про захист персональних даних» від 1 січня 2017 р.; «Про інформацію» від 1 січня 2017 р.; «Про внесення змін до Господарського процесуального кодексу України, Цивільного процесуального кодексу України, Кодексу адміністративного судочинства України та інших законодавчих актів» від 3 жовтня 2017 р. та інші.

Водночас Стратегія розвитку інформаційного суспільства в Україні від 20 травня 2015 р., Стратегія реформування судоустрою, судочинства й суміжних правових інститутів на 2015-2020 рр. від 20 травня 2015 р. та Концепція розвитку електронного урядування в Україні від 20 вересня 2017 р. визначають основні орієнтири розвитку та модернізації судового процесу взагалі й інституту апеляційного провадження зокрема.

Вивчення міжнародного досвіду, пов'язаного 3 питанням впливу діджиталізації на розвиток судової системи, дозволяє визначити основні напрями трансформації інституту апеляційного провадження. Так, наприклад, в Естонії система штучного інтелекту вже виносить рішення по суті на рівні першої інстанції за нескладними справами: дорожньо-транспортна пригода, розлучення, стягнення заборгованості за комунальні послуги тощо. Людина-суддя, що з'являється лише на рівні апеляції, лише перевіряє рішення на наявність юридичних помилок. Справ, у яких має розібратися суддя особисто, отже, винести рішення, може бути 10-15\% від загальної кількості [5]. Даний приклад свідчить про світові тенденції розгляду судових справ на рівні апеляції та визначає, що через певний час у національній системі правосуддя під час розгляду та вирішення нескладних справ буде застосовуватися СШІ. Застосування системи штучного інтелекту - це перевірений і ефективний механізм здійснення правосуддя. Особливо це актуально в сучасних умовах. Наприклад, зараз у ЄДРСР 83 млн рішень [5], які важко швидко проаналізувати людині. Водночас належна програма за декілька секунд здатна за ключовими словами знайти необхідне судове рішення, СШ легко здійснює пошук судових справ і рішень, фабула яких збігається з тією справою, яку розглядає суддя.

У тих країнах, де в діяльності судів використовують СШІ, діє принцип «судді повинні ухвалювати рішення з урахуванням усіх обставин» . Даний принцип передбачає, що підготовчу функцію в пошуку необхідної інформації в безмежному океані інформації, її первинну оцінку й аналіз здійснює система штучного інтелекту. Функція судді обмежується ухваленням судових рішень. Так, можна навести перелік країн, де діє принцип «судді повинні ухвалювати рішення з урахуванням усіх обставин», це країни Азії та Латинської Америки, Хорватія, Румунія, Угорщина й інші [5]. Цей перелік кожного року лише розширюється.

Діджиталізація докорінно змінює парадигму публічної комунікації, розставляє по-іншому акценти - не тільки в тому, як ми комунікуємо, але й що ми комунікуємо. Нові цифрові технології дозволяють створювати і поширювати величезні обсяги інформації майже необмеженому колу осіб - швидко, якісно, без будь-яких істотних витрат. Використання цих технологій зумовлює застосування найкращих світових практик (наприклад, частина інформації має зберігатися у хмарі, а частина - на центральному державному сервері).

Результатами діджиталізації інституту апеляції буде прозорість судової системи; спрощений доступ зацікавлених осіб до системи правосуддя, як наслідок, покращення іміджу та зростання довіри до служителів Феміди.

3 огляду на все вищезазначене, очевидно, саме напрям діджиталізації та підлаштування її під потреби громадян, юридичних осіб - один з основних векторів розвитку інституту апеляції на найближчі роки. Діджиталізація інституту апеляційного провадження - це зміни у процедурах апеляційного провадження, урегульовані законодавством у форматі end-to-end direct online procedure. Результатами такого впливу є: «осучаснення» інституту апеляційного провадження завдяки цифруванню документів, отже, спрощена процедура доступу до апеляційних адміністративних судів; підвищення оперативності перегляду судових рішень; підвищення рівня економічності процедури перегляду судових рішень судів першої інстанції; оперативність отримання інформації стейкхолдерами й інші позитивні моменти. Діджиталізація - це важливий драйвер удосконалення і трансформації інституту апеляційного провадження.

\section{Jimepamypa}

1. В Украине запустили мобильное приложение «Дія» («Государство в смартфоне»). URL: https: //pravo. ua/v-ukraine-zapustili-gosudarstvo-v-smartfone-dija/.

2. Туль С. Сучасні методики інтегральної оцінки діджиталізації світової економіки та ринку праці. Причорноморські еконолічні студії : науковий журнал. 2019. Вип. 42. С. 12. URL: http://bses.in.ua/ journals/2019/42_2019.pdf.

3. Данилишин Б. Про драйвери зростання. Які головні тактичні завдання економічного розвитку України? URL: https: //day.kyiv.ua/uk/blog/suspilstvo/prodrayvery-zrostannya.

4. Vectors of Digital Transformation. OECD Digital Economy Papers. № 273. OECD Publishing. Paris, 2019. URL: https://doi.org/10.1787/5ade2bba-en. 
5. Мищенко И. Качественных решений и единства практики можно достичь только диджитализировав суды. URL: https: //jurliga.ligazakon.net/ analitycs/191352 kachestvennykh-resheniy-i-edinstvapraktiki-mozhno-dostich-tolko-didzhitalizirovav-sudy--sudya-kkhs-vs-ivan-mishchenko.

6. Кобенко О.Діджиталізація як нова ера розвитку корпоративного права. URL: https: //sud.ua/ $\mathrm{ru} /$ news/blog/145948-didzhitalizatsiya-yak-nova-erarozvitku.

7. Мороз В. Електронний суд: міф чи реальність? URL: http: //yur-gazeta.com/publications/practice/ sudova-praktika/elektronniy-sud-mif-chi-realnist.

8. Положення про автоматизовану систему документообігу суду, затверджене рішенням Ради суддів України від 26 листопада 2010 р. № 30 (у редакції рішення РСУ від 12 квітня 2018 р. № 16). URL: https://zakon.rada.gov.ua/rada/show/vr030414-10/ sp:side:max 15 .

9. Цифрове відображення. URL: https://pravo. ua/articles/cifrove-vidobrazhennja.

10. Кодекс адміністративного судочинства України : Закон України від 6 липня 2005 р. № 2747-IV. URL: http://zakon. rada.gov.ua/laws/show/2747-15.

11. Про повернення на доопрацювання проєкту Положення про Єдину судову інформаційно-телекомунікаційну систему : рішення Вищої ради правосуддя від 28 лютого 2019 р. № 624/0/15-19. URL: http: // search.ligazakon.ua/1_doc2.nsf/link1/MUS31575.html.

12. Клауке М. Електронне судочинство - основа відсутності корупції в судовій системі. URL: https:// nv.ua/ukr/biz/markets/elektronne-sudochinstvoosnova-vidsutnosti-korupciji-v-sudoviy-sistemi-martinklauke-50058505.html.

13. Муха Д. Електронний суд: в чому проблема? URL: http: //yur-gazeta.com/publications/practice/ sudova-praktika/elektronniy-sud-v-chomu.

14. Венгриняк X. Все, що потрібно знати про електронний суд. URL: http://yur-gazeta.com/publications/ practice/sudova-praktika/vse-shcho-potribno-znati-proelektronniy-sud.html.

\section{Анотація}

Кравченко К. В. До питання діджиталізації інституту апеляційного провадження. - Стаття.

Стаття присвячена дослідженню впливу діджиталізації на інститут апеляційного провадження в Україні. Розглянуто поняття «діджиталізація», зокрема як триаспектну категорію, що дозволяє розкрити сутність зазначеного вектора розвитку правосуддя. Обгрунтовано, що діджиталізація докорінно змінюе парадигму публічної комунікації. Наголошено на доцільності використання міжнародного досвіду під час трансформації інституту апеляції в Україні. Пов'язано це $з$ тим, що в сучасних умовах, які характеризуються швидким упровадженням цифрових технологій у всі сфери життя, уряд будь-якої країни світу має володіти відповідним інструментарієм, що забезпечує процеси ухвалення рішень у питаннях формування цифрової економіки та діджиталізації судової системи. У зв'язку із цим особливого значення набувають питання правового забезпечення діджиталізації судів. Окреслено правове підгрунтя для застосування цифрових технологій у системі правосуддя. 3 метою розуміння напрямів розвитку інституту апеляції ці напрями визначені з урахуванням міжнародного досвіду, на прикладі Естонії, Гонконгу, Великобританії, Бразилії й інших країн. Акцентовано увагу на принципі «судді повинні ухвалювати рішення з урахуванням усіх обставин», зазначені країни Азії, Латинської Америки, Європи, де він застосовується. Наголошено на проблемах застосування Єдиної судової інформаційно телекомунікаційної системи. Зазначено, що напрям діджиталізації та підлаштування іiї під потреби громадян, юридичних осіб стає одним з основних векторів розвитку інституту апеляції на найближчі роки. Діджиталізація інституту апеляційного провадження передбачає зміни у процедурах апеляційного провадження, урегульовані законодавством у форматі "end-to-end direct online procedure”. Результатами такого формату взаємодії є: «осучаснення» інституту апеляційного провадження завдяки спрощенному доступу до апеляційних адміністративних судів; підвищення оперативності перегляду судових рішень; підвищення рівня економічності процедури перегляду судових рішень судів першої інстанції; оперативність отримання інформації стейкхолдерами й інші позитивні моменти.

Ключові слова: діджиталізація, електронний суд, апеляційне провадження, міжнародний досвід, цифрові технології.

\section{Summary}

Kravchenko $K . V$. On the question of the digitization of the institute of appeal proceedings. - Article.

The article is devoted to the study of the impact of digitization on the Institute of Appeal Proceedings in Ukraine. The concept of "digitization" is considered, in particular as a three-dimensional category, which allows to reveal the essence of this vector of development of justice. It is justified that digitization radically changes the paradigm of public communication. It is emphasized on the expediency of using international experience in transformation of the Institute of Appeal in Ukraine and it is connected with the fact that in the modern conditions characterized by the rapid introduction of digital technologies in all spheres of life, the government of any country in the world should have the appropriate tools to ensure the processes decision-making on the digital economy and the digitization of the judiciary. In this regard, the issue of legal support for court digitization of courts is of particular importance. The legal basis for the use of digital technologies in the justice system is outlined. In order to understand the directions of development of the Institute of Appeal, these areas have been defined in the light of international experience such as Estonia, Hong Kong, the United Kingdom, Brazil and others. Emphasis is placed on the principle that "judges must decide in all circumstances" and the countries of Asia and Latin America, Europe where applicable. The problems of implementation of the Unified Judicial Information and Telecommunication System have been emphasized. It is noted that the direction of digitization and adjustment of it to the needs of citizens and legal entities - is becoming one of the main vectors for the development of the Institute of Appeal in the coming years. The privatization of the Institute of Appeal Proceedings provides for changes in the appeal proceedings, regulated by law, in the format of "endto-end direct online procedure". The consequences of this form of interaction are the "modernization" of the institution of appeal proceedings through simplified access to administrative courts; increase of efficiency of review of court decisions; improving the level of efficiency of the procedure for reviewing court decisions of first instance courts; prompt receipt of information by stakeholders and other positive points.

Key words: digitization, e-court, appeal proceedings, international experience, digital technologies. 